\title{
Konstruksi Makna Aktivitas Jurnalistik Bagi Pelajar Anggota Komunitas Hai School Crew
}

\author{
Syifa Nuri Khairunisa, Henny Srimulyani, Ipit Zulfan \\ Fakultas Ilmu Komunikasi, Universitas Padjadjaran \\ hennysrimulyani@gmail.com
}

\begin{abstract}
Hai School Crew (HSC) is a community of high school students whose activities are supervised by Hai Online media. Through this community, the members could participate in editorial activities carried out by the Hai Online editorial staff. This study aimed to determine the motives, experiences, and meanings of journalistic activities for students as community members who carried out journalistic activities through the Hai School Crew community. This study used a qualitative research method with a phenomenological approach conducted on seven members of the Hai School Crew (HSC) community. The results showed the construction process of the meaning of journalistic activities experienced by students of HSC members. Students initially possessed motives that encourage them to participate in the HSC community. Subsequently, the students carried out a variety of journalistic activities that enabled them to gain a variety of experiences regarding journalism. Afterward, students would create routines about the editorial process they went through to make it a habit of doing their work in the editorial activity of Hai Online. These experiences form their specific knowledge about journalism, which would shape the meaning of journalistic activities they carried out through the HSC community. The informants interpret journalistic activities as an activity to find news and then express it in written form according to the facts. The meaning of the activities they experienced in the HSC community is as a means of learning how journalists work every day. This study concludes that by carrying out journalistic activities routinely, the informants obtained motives, experiences, and meanings of journalistic activities so that they could understand their role as participants whose job is to emulate professional journalists. This research suggests HSC members can continue to maintain their existence and continue to actively carry out journalistic activities that are of interest to the youth
\end{abstract}

Keywords: journalistic activities; meanings of journalistic activity; motives; experiences

\begin{abstract}
Abstrak
Hai School Crew (HSC) adalah sebuah komunitas pelajar SMA yang berada di bawah naungan media Hai Online, tempat anggotanya melakukan kegiatan keredaksian yang dilakukan oleh redaksi Hai Online. Penelitian ini bertujuan untuk mengetahui motif, pengalaman, dan makna aktivitas jurnalistik bagi pelajar anggota komunitas yang menjalankan aktivitas jurnalistik lewat komunitas HSC. Penelitian ini menggunakan pendekatan fenomenologi terhadap tujuh pelajar yang menjadi anggota komunitas HSC. Hasil penelitian menunjukkan proses konstruksi makna aktivitas jurnalistik yang dialami oleh para pelajar. Para pelajar awalnya memiliki beberapa motif untuk berpartisipasi di komunitas HSC. Motif tersebut mendorong pelajar melakukan berbagai aktivitas jurnalistik, sehingga memberi pengalaman tentang kejurnalistikan. Pengalaman yang menjadi rutinitas membentuk kebiasaan dalam melakukan pekerjaan mereka di redaksi Hai Online. Pengalaman tersebut kemudian membentuk pengetahuan khusus serta membangun pemaknaan tentang aktivitas jurnalistik yang mereka lakukan lewat komunitas HSC. Para informan memaknai aktivitas jurnalistik sebagai sebuah kegiatan mencari berita yang dituangkan ke dalam bentuk tulisan. Makna kegiatan yang mereka lakukan adalah sebagai sarana mempelajari bagaimana jurnalis bekerja. Simpulan dari penelitian ini adalah dengan menjalankan aktivitas jurnalistik secara rutin, para informan memperoleh motif, pengalaman, dan makna aktivitas jurnalistik, sehingga
\end{abstract}

Korespondensi: Dr. Henny Sri Mulyani, M.Si., Prodi Jurnalistik Universitas Padjadjaran, Jl. Raya bandung Sumedang Km 21, 081321949474, Email: hennysrimulyani@gmail.com Menyerahkan: Maret 2020, Diterima: Juli 2020, Terbit: Juli 2020

ISSN: 2549-0559 (cetak), ISSN: 2549-1946 (online), Website: http://jurnal.unpad.ac.id/kajian-jurnalisme 
mereka bisa memahami perannya sebagai seorang partisipan yang memiliki tugas layaknya jurnalis profesional. Saran penelitian ini adalah agar para anggota HSC bisa terus mempertahankan eksistensi mereka dan terus aktif melakukan aktivitas jurnalistik yang menarik bagi remaja.

Kata kunci: aktivitas jurnalistik; makna aktivitas jurnalistik; motif; pengalaman.

\section{PENDAHULUAN}

Dalam sebuah artikel yang dimuat dalam disitus The Nation yang berjudul "Student Journalists are Our Future - We Should Start Treating Them Like It" yang ditulis oleh William Anderson pada 11 Juli 2017 lalu disebutkan bahwa Catherine Palmer, seorang reporter di koran kampus The John Hopkins News-Letter pernah meliput peristiwa demonstrasi besar di Amerika Serikat. Saat demonstrasi yang berlangsung tak jauh dari kampusnya, Catherine jadi salah satu wartawan yang pertama tiba. Kemudian menyusul beberapa wartawan dari media massa lain. Karena kecepatan Cathrine mencapai sumber berita tersebut, eksklusivitas berita yang diterbitkan koran Universitas John Hopkins ini menjadi tak ternilai (Anderson, 2017).

Dalam kegiatan jurnalistik seorang wartawan/jurnalis/reporter diharuskan memiliki nose of news (Kusumadiningrat, 2005). Hal ini harus mereka miliki agar bisa mencari berita yang kadang kala tersembunyi dan bahkan sulit untuk didapatkan. Jika merujuk pada artikel yang ditulis oleh Anderson di atas, kejadian yang dialami oleh Catherine Palmer ketika meliput suatu kejadian yang ada di sekitar lingkungan kampus menjadi sebuah keuntungan yang dimiliki oleh wartawan pelajar. Pelajar lebih jeli dan memiliki akses yang lebih besar untuk bisa mendapatkan berita di sekitar mereka.

Potret wartawan pelajar memang tak asing di dunia jurnalistik, termasuk di Indonesia. Sebagian dari masyarakat mungkin lebih familiar dengan wartawan pelajar dalam bentuk pers pelajar yang berada di bawah naungan media sekolah atau kampus mereka. Namun, beberapa media massa konvensional ternyata tak menutup mata soal potensi yang dimiliki para pelajar ini. Beberapa sudah memanfaatkannya untuk kepentingan redaksional media massa mereka. Salah satu caranya adalah lewat pengadaan komunitas yang diasuh oleh anggota redaksi media massa.

Komunitas yang dimaksud adalah sebuah cara untuk membangun hubungan dengan pembaca dan bekerja sama dengan mereka untuk memproduksi konten jurnalistik yang terbaik. Menurut Paul Bradshaw, pengadaan komunitas oleh redaksi sebuah media massa harus dilakukan untuk memastikan adanya hubungan yang kuat antara media dan pembaca sehingga diharapkan para anggota komunitas ini bisa membantu para jurnalis dalam membuat konten jurnalistik (Bradshaw, 2017). Hal itu memberikan komunitas sebuah posisi yang sangat penting dalam proses jurnalistik. Para anggota komunitas biasanya berasal dari pembaca setia media tersebut yang memiliki passion di bidang jurnalistik. Fungsi masing-masing komunitas tersebut kemudian bergantung kepada aturan media yang menaunginya. Namun biasanya para anggota komunitas akan dilibatkan dalam proses jurnalistik yang terjadi dalam media tersebut.

Banyak media massa yang menganggap komunitas memiliki potensi yang sangat besar. Bentuk komunitas yang ada di media massa di Indonesia pun beragam. Satu yang menarik adalah komunitas yang berisikan pelajar Sekolah Menengah Atas (SMA) yang terlibat dalam kegiatan media massa bersegmentasi remaja. Para pelajar SMA ini memiliki umur yang relatif sama dengan segmentasi khalayak media tersebut. Mereka memproduksi konten jurnalistik untuk dibaca khalayak sebaya. Beberapa media massa yang memiliki komunitas untuk pelajar adalah Kompas dengan program Kompas MuDA, Kedaulatan Rakyat dengan program Kaca, Kumparan dengan program SPEAR, Hai Online dengan program Hai School Crew, dan 
Volume 04 Nomor 01 Tahun 2020

DOI: $10.24198 /$ jkj.v4i1.26614

Provoke dengan program Repro.

Semua komunitas yang dinaungi oleh media-media besar di Indonesia ini punya ciri khas berbeda-beda. Masing-masing punya kegiatan dan tujuan yang berbeda pula. Sebagian media hanya menyediakan tempat saja untuk para pelajar yang ingin membuat karya jurnalistik untuk bisa dimuat di media mereka. Ada juga media yang mengorganisasikan kegiatan komunitas tersebut hanya untuk bersenang-senang saja. Namun, ada juga media massa yang benar-benar mengajak para pelajar untuk berkolaborasi menjadi bagian dari aktivitas keredaksian mereka. Para pelajar tersebut dinaungi, dibimbing, dan diajak untuk memproduksi konten jurnalistik.

Salah satu media massa yang memandang komunitas sebagai suatu hal yang potensial adalah Hai Online. Sejak awal berdiri pada 1977 hingga sekarang, Hai Online yang merupakan media massa bersegmentasi remaja jadi pelopor adanya komunitas pembaca yang terlibat dalam kegiatan redaksi dalam media massa. Berdasarkan wawancara peneliti pada bulan Mei 2019 dengan mantan managing editor dan pembina komunitas ini, Rizki Ramadan, media komunitas bisa menjadi sarana dalam meningkatkan engagement antara khalayak dengan media. Hai Online berusaha untuk memanfaatkan para pelajar yang jadi pembaca mereka untuk terlibat secara aktif dalam kegiatan redaksi yang mereka lakukan. Selain itu, kebutuhan untuk mendapatkan konten seputar remaja membuat jurnalis Hai seringkali mencari dan memperdalam topik melalui diskusi dengan anggota komunitas HSC. Opsi untuk melibatkan khalayak khususnya para pelajar ini sudah menjadi prioritas Hai sejak lama. Sebagai media yang menyasar khalayak remaja, Hai Online merasa perlu untuk mengajak langsung para pembacanya agar bisa berinteraksi dengan redaksi Hai Online.

Para pelajar yang terlibat dalam komunitas ini menjalani berbagai pengalaman dalam peran mereka sebagai "wartawan" untuk Hai Online. Mereka memiliki hak dan kewajiban sebagai anggota yang memungkinkan para pelajar tersebut untuk mendapat berbagai pengalaman layaknya wartawan profesional. Para pelajar ini sempat melakukan berbagai proses dalam aktivitas jurnalistik yang mereka lakukan. Mereka mencari berita, meliput berita, mewawancara narasumber, dan menulis berita. Sehingga menarik untuk mengetahui pengalaman-pengalaman macam apa yang dialami oleh para pelajar tersebut. Berdasarkan hasil wawancara dengan Rizki Ramadan dan pengamatan peneliti di lapangan, para pelajar tersebut biasanya tidak memiliki pengalaman seputar jurnalistik yang membuat mereka cukup kredibel untuk bisa beraktivitas layaknya seorang wartawan. Minimnya pengetahuan dan pengalaman berakibat pada munculnya berbagai tantangan dan kendala selama menjalani aktivitas jurnalistik di komunitas HSC. Baik itu tantangan saat melakukan peliputan berita, wawancara narasumber, atau penulisan berita. Dari tantangan-tantangan tersebut para pelajar ini mempelajari banyak hal yang berdampak pada pengetahuan dan kemampuan mereka melakukan aktivitas jurnalistik.

Selain aktif di HSC, mereka masih memiliki tugas utama sebagai seorang pelajar. Salah satu kesulitan yang dialami mengenai pembagian waktu antara dua kegiatan yang mereka jalani ini. Bagi seorang remaja, saat seperti ini merupakan masa mencari pengaman yang sebanyakbanyaknya. Masa remaja atau adolesence adalah periode yang sangat penting dalam pencarian jati diri dan membina keyakinan tentang diri. Menurut Leta Hallingworth, remaja harus menemukan otherself dirinya yang meliputi semua pengalaman yang membentuk kesadaran seseorang tentang keberadaannya, ide-idenya, dan sikap-sikapnya yang telah berkembang sejak masa kanak-kanak (Sulaeman \& Hamalik, 1995). Dalam konteks ini, Komunitas HSC mampu menjadi sarana pencarian pengalaman yang berharga bagi para remaja ini.

Para remaja anggota komunitas HSC ini sebagian besar memiliki semangat yang tinggi dalam berkarya. Dalam penelusuran data yang dilakukan terhadap mantan pembina HSC, ditemukan bahwa para pelajar ini punya rasa penasaran dan gairah yang tinggi dalam 
menjalankan aktivitas jurnalistik. Merujuk hal itulah Kiram merasa bahwa para pelajar ini bisa menjadi regenerasi yang baik untuk pekerja media massa Indonesia di masa depan. Sebagian besar pelajar yang sempat menjadi anggota komunitas HSC memutuskan bahwa mereka ingin meneruskan kegiatan mereka di dunia jurnalistik. Ada yang bergabung sampai dua tahun berturut-turut dengan komunitas ini, ada juga yang melanjutkan kuliah di jurusan komunikasi yang bisa membantu mereka untuk tetap aktif di dunia jurnalistik.

Komunitas HSC jadi salah satu potensi dalam media baru. Komunitas semacam ini bisa termasuk ke dalam praktik jurnalisme partisipatif. Jurnalisme partisipatif menurut Bowman dan Willis adalah :

"The act of a citizen, or group of citizens, playing an active role in the process of collecting, reporting, analyzing, and disseminating news and information. The intent of this participation is to provide independent, reliable, accurate, wide-ranging and relevant information that a democracy requires."(Bowman \& Willis, 2003).

Jurnalisme partisipatif sendiri dikenal dengan berbagai nama, ada yang menyebutnya user generated content dan citizen journalism atau jurnalisme warga. Para prinsipnya jurnalisme partisipatif memungkinkan orang yang ada di dalam newsroom yaitu para wartawan profesional dan di luar newsroom yaitu para anggota komunitas untuk saling terlibat dalam komunikasi satu sama lain. Mereka melakukan proses berkelanjutan dalam produksi berita dan membangun komunitas yang aktif (Singer et al., 2011).

Medium jurnalisme partisipatif dapat berupa media tradisional seperti radio atau media baru yaitu media online. Di Indonesia praktik jurnalisme partisipatif telah dikenal sejak jurnalisme di radio berkembang di awal tahun 1990an (Yudhapramesti, 2007). Jurnalisme yang melibatkan orang-orang biasa ini telah lama dikenal sebagai sarana pemberdayaan warga (Santoso, 2019). Jurnalisme partisipatif memungkinkan orang di dalam dan di luar newsroom untuk bisa berkolaborasi dan terlibat dalam proses pembuatan konten, dan di saat yang bersamaan membangun sebuah komunitas yang aktif. Jurnalisme partisipatif kemudian juga berkembang pada berbagai media termasuk media baru (media online) dan media sosial (Ritonga \& Syahputra, 2019).

Era media baru memang memungkinkan berbagai hal terjadi dalam proses jurnalistik yang ada dalam newsroom. Praktik ini juga termasuk ke dalam penerapan salah satu elemen jurnalisme yang diuraikan oleh Kovach dan Rosenthiel. Kesembilan elemen tersebut adalah; kewajiban pertama jurnalisme adalah pada kebenaran, loyalitas pertama jurnalisme adalah kepada warga, esensi jurnalisme adalah disiplin verifikasi, jurnalis harus tetap independen dari pihak yang mereka liput, jurnalis harus melayani sebagai pemantau independen terhadap kekuasaan, jurnalisme harus menyediakan forum bagi kritik maupun komentar dari publik, jurnalisme harus berupaya membuat hal yang penting itu menarik dan relevan, jurnalis harus menjaga agar beritanya komprehensif dan proporsional, serta jurnalis memiliki kewajiban untuk mengikuti suara nurani mereka (Kovach, B., \& Rosenstiel, 2001). Beberapa tahun kemudian, ketika era internet dan media baru muncul, Kovach dan Rosenthiel pun memperbaharui elemen jurnalisme menurut mereka menjadi sepuluh elemen jurnalisme. Elemen kesepuluh tersebut adalah warga juga memiliki hak dan tanggung jawab dalam hal-hal yang terkait dengan berita.

Elemen ini menjelaskan bahwa para pembaca bukan lagi hanya konsumen pasif dari media, tapi mereka juga bisa menciptakan media mereka sendiri atau setidaknya terlibat dalam proses jurnalistik yang ada di media massa. Bentuknya memang bemacam-macam. Ada blog, jurnalisme partisipatif atau jurnalisme warga, media alternatif, media komunitas, dan lain-lain. Komunitas pelajar di atas juga termasuk ke dalam penerapan elemen kesepuluh ini.

Walaupun memiliki banyak potensi, sayangnya banyak media yang belum secara serius 
menggarap program komunitas ini. Berdasarkan pengamatan yang lakukan terhadap mediamedia di Indonesia, sedikit sekali yang benar-benar memberi tempat khusus untuk para anggota komunitas khususnya komunitas pelajar untuk berkarya. Komunitas-komunitas yang ada kemunculannya seringkali tenggelam, beberapa bahkan hanya terlihat kiprahnya di awal saja, ketika peneliti ingin mencari karya-karya para anggota komunitas yang dimuat di media, cenderung sulit sekali ditemukan.

Oleh karenanya menjadi penting untuk mengetahui potensi jurnalistik apa yang bisa ditawarkan oleh komunitas pelajar khususnya komunitas HSC. Potensi ini dapat ditelusuri melalui kajian terhadap konstruksi makna aktivitas jurnalistik para pelajar anggota komunitas Hai School Crew. Penelitian ini mengungkap motif yang mendorong para pelajar untuk mau terlibat di komunitas HSC, kemudian pengalaman-pengalaman yang mereka lalui dalam menjalankan aktivitas jurnalistik, serta makna mengenai aktivitas yang mereka bentuk. Temuan akan motif dan pengalaman ini dapat menunjukkan aspek-aspek pengetahuan jurnalistik yang dimiliki oleh para pelajar tersebut. Penelitian ini menjabarkan bagaimana aktivitas jurnalistik yang dilakukan oleh para pelajar tersebut dapat mengubah cara berpikir dan cara pandang mereka soal jurnalistik, serta sedalam apa kemampuan mereka dalam memproduksi konten jurnalistik yang berkualitas.

Penelitian ini juga menguraikan bagaimana pengalaman para pelajar anggota komunitas HSC dalam melakukan aktivitas jurnalistik yang membentuk pemaknaan terhadap aktivitas jurnalistik itu sendiri. Bagaimana para pelajar tersebut memiliki motif untuk bergabung dengan komunitas HSC ini, serta perjalanan pengalaman mereka termasuk pengalaman melalui berbagai tantangan dan kendala. Berbagai pengalaman tersebut kemudian memunculkan motif lanjutan untuk terus aktif dalam kegiatan hingga akhirnya mereka bisa memaknai aktivitas jurnalistik yang mereka lakukan.

\section{METODE}

Penelitian ini menggunakan metode penelitian kualitatif dengan paradigma konstruktivis dan pendekatan fenomenologi. Peneliti kualitatif dapat mengembangkan tradisi penelitiannya menurut pengalaman yang dia dapatkan selama melakukan penelitian tersebut (Kuswarno, 2007). Peneliti memilih untuk menggunakan metode kualitatif karena dirasa paling sesuai untuk mengupas masalah yang berkaitan dengan pemaknaan. Selain itu, dengan menggunakan metode fenomenologi, peneliti akan mampu memberikan informasi lebih dalam tentang dunia dari sudut pandang orang yang mengalaminya secara langsung yang berkaitan dengan sifatsifat alami pengalaman manusia, dan makna yang ada padanya.

Untuk memperdalam analisis dalam penelitian ini, peneliti menggunakan teori fenomenologi dan teori konstruksi realitas sosial sebagai pisau analisis. Menurut teori fenomenologi Schultz, tindakan manusia akan mengalami dua fase, yaitu fase tindakan inorder-to motive dan fase tindakan because-motive. Fase in-order-to motive merupakan fase tindakan yang merujuk pada masa yang akan datang. Sementara fase because-motive adalah fase tindakan yang merujuk pada masa lalu. Peneliti akan melihat motif yang dimiliki oleh para informan dengan menggunakan dua fase tindakan ini. Dengan begitu, akan diketahui motifmotif macam apa yang mendasari tindakan para informan dalam menjalani aktivitas jurnalistik lewat komunitas HSC. Apakah motif tersebut termasuk ke dalam because-motive, atau inorder-to motive.

Selain teori fenomenologi, peneliti juga akan menggunakan teori konstruksi realitas sosial dari Peter Berger dan Thomas Luckmann. Menurut mereka, ada tiga macam realitas, yaitu realitas objektif, realitas subjektif, dan realitas intersubjektif. Realitas sendiri merupakan 
proses dialektif yang berlangsung dalam proses simultan antara ketiga realitas tadi. Bagi Berger dan Luckmann, proses sosial akan diciptakan oleh individu yang secara terus menerus menciptakan suatu realitas yang mereka miliki dan alami bersama secara subjektif (Bungin, 2008).

Realitas sosial adalah pengetahuan yang bersifat keseharian yang hidup dan berkembang di masyarakat, seperti konsep, kesadaran umum, dan wacana publik sebagai hasil dari konstruksi sosial. Realitas sosial dikonstruksi melalui proses eksternalisasi, objektivasi, dan internalisasi (Bungin, 2008:192). Hal yang sama berlaku terhadap realitas sosial yang dikonstruksi oleh para pelajar anggota komunitas HSC ini.

Penelitian ini menjabarkan realitas yang dialami para pelajar anggota komunitas HSC dengan tiga tahapan tersebut. Proses eksternalisasi terjadi pada saat para pelajar anggota komunitas HSC mulai mengenal komunitas HSC dan aktivitas jurnalistik di dalamnya, serta memiliki motif dan alasan untuk berkolaborasi dalam komunitas tersebut. Kemudian mereka akan mengalami proses objektivasi ketika mulai melakukan proses jurnalistik secara berulang. Itu termasuk interaksi dengan narasumber dan sumber berita saat liputan, atau ketika melakukan pencarian fakta terhadap isu yang sedang diliput. Terakhir adalah proses internalisasi yang dihasilkan dari proses eksternalisasi dan objektivasi yaitu, pemaknaan yang dimiliki oleh para pelajar anggota komunitas HSC terhadap aktivitas jurnalistik setelah pengalaman mereka melakukan proses jurnalistik secara berulang.

Pengumpulan data penelitian dilakukan melalui observasi, wawancara mendalam, dan studi kepustakaan. Dalam melakukan wawancara peneliti menentukan informan menggunakan sampel purposif dengan menentukan kelompok peserta yang menjadi informan sesuai kriteria terpilih dan relevan dengan masalah penelitian tertentu. Berdasarkan maksud dari pemilihan sample tersebut, peneliti menentukan beberapa kriteria untuk mengklasifikasikan subjek penelitian yang akan dijadikan sampling. Kriteria tersebut adalah; telah menjadi anggota aktif dari komunitas HSC minimal 6 bulan, tulisannya pernah dimuat di majalah Hai dan/atau laman Hai Online, pernah melakukan reportase dan penulisan berita, pernah mewawancarai narasumber atau sumber berita, bersedia diwawancara atau direkam aktivitasnya selama wawancara atau ketika penelitian berlangsung, mampu menggambarkan kembali fenomena yang telah dialaminya, serta bersedia memberikan persetujuan untuk mempublikasikan hasil penelitian.

Peneliti mewawancarai tujuh orang yang memenuhi kriteria yang sudah disebutkan di atas. Ketujuh orang tersebut adalah para pelajar SMA anggota komunitas HSC yang peneliti rasa sudah memenuhi kriteria yang sudah ditentukan sebelumnya. Para informan ini berasal dari berbagai daerah di Indonesia, khususnya Jabodetabek. Ketujuh informan tersebut adalah Dio (Jakarta Timur), Maria (Jakarta Timur), Anya (Jakarta Selatan), Medio (Yogyakarta), Hadistia (Tangerang Selatan), Halim (Depok), dan Kayla (Jakarta Pusat). Pertanyaan yang peneliti ajukan berkaitan dengan proses kerja, pemaknaan, dan bentuk sosialisasi yang mereka terapkan saat melakukan aktivitas jurnalistik untuk Hai Online. Wawancara mendalam yang peneliti lakukan ini dilakukan secara informal dalam bentuk percakapan (interaktif) serta pertanyaan dengan jawaban terbuka. Setelah itu peneliti menguji keabsahan data dengan beberapa langkah, beberapa di antaranya adalah konfirmasi kepada beberapa peneliti lain, konfirmasi kepada pihak Hai Online, dan konfirmasi kepada para pelajar yang menjadi informan, kemudian menggolongkan data di bawah dengan data yang sama/cocok.

\section{HASIL DAN PEMBAHASAN}

Pada bagian ini, peneliti akan menjabarkan bagaimana proses para informan penelitian 
bisa memaknai aktivitas jurnalistik. Pemaknaan mengenai aktivitas jurnalistik ini diperoleh dari pengalaman yang dialami para informan. Pengalaman yang para informan alami benarbenar merupakan pengalaman yang dialami oleh setiap informan.

Pembahasan mencakup hal yang memenuhi tujuan penelitian, yaitu mengenai motif informan, pengalaman informan, dan pemaknaan informan terhadap aktivitas jurnalistik. Ketiga hal tersebut adalah realitas yang terkonstruksi oleh individu dari proses yang mereka lalui selama menjalani aktivitas jurnalistik serta dari proses interaksi yang para informan lakukan dengan individu lainnya yang terlibat dalan aktivitas jurnalistik tersebut.

\section{Motif Bergabung dengan Komunitas Hai School Crew}

Sebelum memutuskan untuk bergabung dengan komunitas Hai School Crew, para informan pasti memiliki motif yang mendorong mereka. Motif-motif yang mereka miliki ini kemudian berubah seiring berjalannya waktu karena berbagai pengalaman yang para informan alami. Dengan mencari tahu motif tersebut, kita akan mampu untuk melihat tujuan yang coba dicapai oleh para pelajar tersebut dan bagaimana hal itu mempengaruhi keputusan mereka di masa depan.

Dari ketujuh informan yang diwawancarai dalam penelitian ini, hampir semuanya memiliki motif yang sama dalam bergabung di komunitas HSC. Untuk bisa lebih mudah dipahami, peneliti akan menggunakan klasifikasi motif. Alfred Schutz dalam fenomenologi membagi motif seseorang melakukan tindakan sosial menjadi dua, yaitu in-order-to motive atau motif yang berorientasi pada masa depan, dan because motive atau motif yang berorientasi pada masa lalu.

Dari hasil wawancara, terlihat ada enam motif yang dimiliki oleh para informan. Motifmotif tersebut adalah; menyalurkan hobi dan kemampuan, mendapat pengalaman, bertemu dengan orang-orang yang punya kesamaan minat dan usia, datang ke berbagai acara gratis dan bertemu idola, yang termasuk ke dalam because-motive. Juga ada motif mendapat rekognisi dan status, serta meraih cita-cita yang termasuk ke dalam in-order-to motive.

Dari ketujuh informan, yang memiliki motif menyalurkan hobi dan kemampuan ada tiga orang; Medio, Anya, dan Maria. Kemudian ada lima orang yang memiliki motif mendapat pengalaman; Medio, Dio, Kayla, Halim, dan Hadistia. Lalu ada dua orang, Anya dan Maria yang memiliki motif bertemu dengan orang-orang yang punya kesamaan minat dan usia. Anya, Maria, Kayla, dan Hadistia juga memiliki motif datang ke berbagai acara gratis dan bertemu idola. Motif-motif tersebut termasuk ke dalam because-motive atau motif yang berorientasi pada masa lalu. Setelah mengalami berbagai pengalaman dalam melakukan aktivitas jurnalistik, para informan kemudian akan memiliki motif lanjutan yang berorientasi pada tujuan masa depan yang ingin mereka dapatkan lewat aktivitas jurnalistik di komunitas HSC. Dari seluruh informan, enam informan memiliki motif ini. Anya, Dio, Maria, Kayla, Halim, dan Hadistia memiliki motif meraih cita-cita. Sementara Anya, Dio, Maria, dan Hadistia memiliki motif mendapat rekognisi dan status. Dalam persiapan memaknai aktivitas jurnalisme para informan memiliki motif untuk meyakinkan dirinya menjadi jurnalis (Iqbal \& Sjafirah, 2019).

Motif-motif para informan dalam menjalani aktivitas jurnalistik lewat komunitas HSC ini termasuk ke dalam tahap eksternalisasi dan internalisasi. Motif yang termasuk ke dalam tahap eksternalisasi adalah because-motive, dan motif yang termasuk ke dalam tahap internalisasi adalah in-order-to motive. Tahap eksternalisasi adalah proses penyesuaian diri dengan dunia sosio-kultural sebagai produk manusia (Berger, P. L., \& Luckmann, 2013). Sebelum memutuskan bergabung dengan komunitas HSC dan mencari tahu perihal komunitas tersebut, para informan pasti memiliki motif. Motif-motif tersebut menjadi faktor yang meyakinkan diri mereka untuk menjalani aktivitas jurnalistik. Memiliki motif merupakan faktor penting 
dari tahap eksternalisasi karena menjadi sesuatu yang mendasari para informan untuk bisa memaknai aktivitas jurnalistik.

Setelah memiliki motif because-motive dan menjalani aktivitas jurnalistik, para informan kemudian akan memiliki in-order-to motive. Merujuk pada tahap intersubjektif milik Berger dan Luckmann, in-order-to motive termasuk ke dalam tahap internalisasi yang dialami oleh para informan. Hal itu karena in-order-to motive adalah motif lanjutan yang muncul dalam diri para informan setelah mereka menjalani aktivitas jurnalistik di komunitas HSC.

Diagram 1. Motif Para Pelajar bergabung dengan Komunitas Hai School Crew

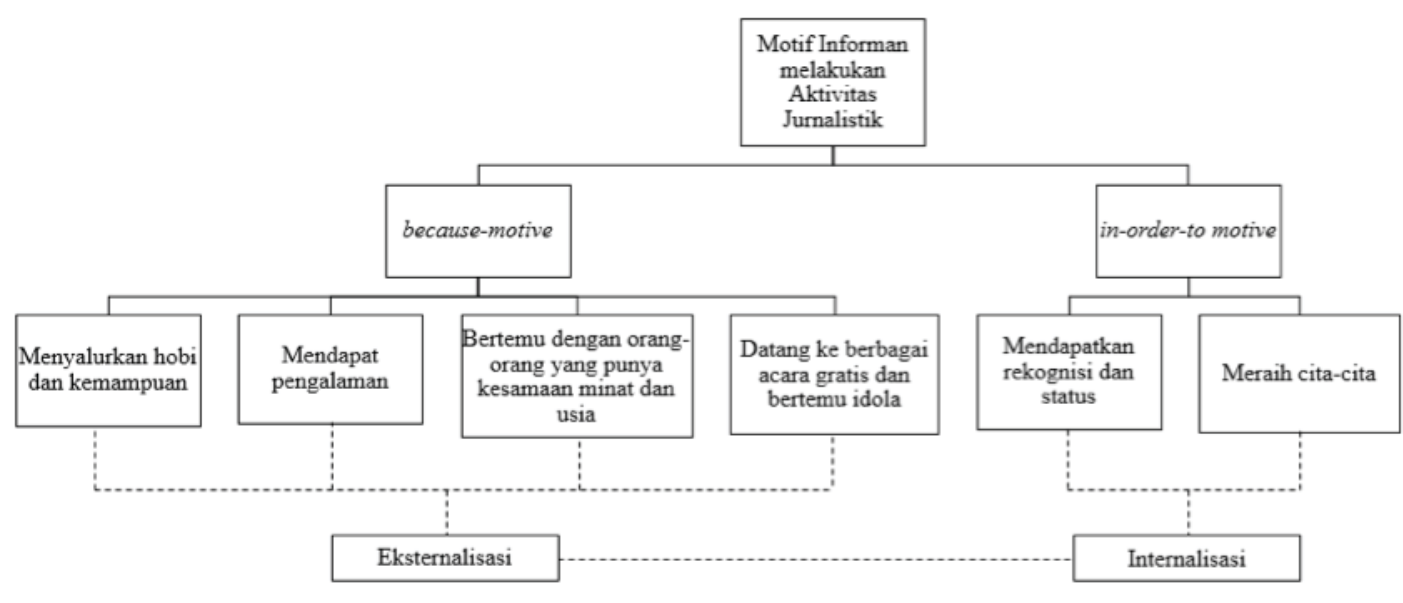

Sumber: Hasil Elaborasi Peneliti

\section{Pengalaman Selama Menjadi Anggota Komunitas Hai School Crew}

Para pelajar yang menjadi informan dalam penelitian ini hampir semuanya memiliki pengalaman yang tidak begitu berbeda. Berdasarkan temuan wawancara, para pelajar ini memaparkan pengalaman mereka saat melakukan aktivitas jurnalistik lewat komunitas HSC yang berada di bawah naungan Hai Online. Para informan menceritakan awal mula mereka mengetahui komunitas HSC dan aktivitas jurnalistik yang ada di dalamnya, serta cara mereka mencari informasi mengenai komunitas HSC. Kemudian para informan juga menceritakan proses kegiatan jurnalistik yang mereka jalani, kendala dan tantangan yang harus mereka hadapi saat menjalankan proses jurnalistik tersebut, dan solusi yang mereka terapkan untuk menghadapi kendala tersebut. Dengan kata lain, para pelajar ini menerapkan jurnalisme partisipatif.

Tahap pertama dalam proses inter-subjektif adalah eksternalisasi, yaitu proses penyesuaian diri dengan dunia sosio-kultural sebagai produk manusia (Berger, P. L., \& Luckmann, 2013). Dunia sosio-kultural dalam penelitian ini adalah aktivitas jurnalistik yang dilakukan oleh anggota komunitas HSC. Semua berawal ketika para informan pertama kali mengetahui komunitas HSC, seperti bentuk organisasi, jenis kegiatannya, dan informasi lainnya yang membuat mereka memutuskan untuk bergabung. Setelah bergabung, para informan pun mulai melakukan aktivitas jurnalistik dengan statusnya sebagai anggota komunitas HSC. Saat inilah para informan mulai mengenali realitas yang akan mereka hadapi.

Selain tahap eksternalisasi, objektivasi, dan internalisasi, para informan juga akan mengalami proses sosialisasi. Menurut Berger dan Luckmann, sosialisasi adalah pengimbahasan individu secara komprehensif dan konsisten ke dalam dunia objektif suatu masyarakat atau salah satu sektornya. Proses ini terbagi menjadi dua, sosialisasi primer dan sekunder (Berger, P. L., \& Luckmann, 2013). Pada tahap eksternalisasi, para informan mengalami sosialisasi 
primer. Sosialisasi primer adalah sosialisasi tahap pertama yang dialami oleh individu. Biasanya sosialisasi ini menjadi tahap yang paling penting. Para informan mengalami sosialisasi primer ketika mereka memasuki dunia sosio-kultural, dalam hal ini adalah dunia jurnalistik, di mana para informan mulai mempersiapkan dirinya untuk melakukan aktivitas jurnalistik. Dalam tahap ini, para informan mulai mencari tahu dan memilih cara apa yang akan mereka tempuh untuk belajar soal jurnalistik.

Pada tahap pengenalan awal, para informan mengetahui informasi mengenai $\mathrm{HSC}$ atau Hai Online dari teman sebaya atau memperoleh informasi dari redaksi Hai Online atau majalah Hai, karena informan memang sudah menjadi pembaca setia Hai. Pada tahap ini terjadi proses eksternalisasi yang dilalui para informan. Para informan mencari tahu soal komunitas HSC dan aktivitas jurnalistik yang akan mereka laksanakan saat itu. Setelah tahap pengenalan selesai, para informan pun masuk ke dalam lingkungan dalam komunitas HSC dan mulai melakukan aktivitas jurnalistik yang jadi inti kegiatan komunitas HSC. Aktivitas jurnalistik ini termasuk ke dalam tahap objektivasi. Pada tahap objektivasi, informan melihat aktivitas jurnalistik pada komunitas HSC sebagai produk sosial. Menurut Berger dan Luckmann, produk sosial dilihat sebagai realitas yang objektif atau proses interaksi sosial dalam dunia inter-subjektif yang dilembagakan atau mengalami proses institusionalisasi.

Dalam kegiatan jurnalistiknya yang mengadopsi konsep jurnalisme partisipatif, anggota komunitas HSC bekerja dengan cara yang fleksibel. Jurnalisme partisipatif yang mengadopsi sistem peer-to-peer memungkinkan orang-orang yang terlibat di dalamnya tidak diawasi dalam sistem editorial secara langsung dan tidak memiliki sistem kerja jurnalistik yang baku. Menurut Bowman dan Willis, orang-orang yang terlibat dalam praktik jurnalisme partisipatif akan punya derajat yang setara dan seringkali bisa berganti-ganti peran. Produk atau berita yang mereka hasilkan sering kali tidak disaring oleh mediator (atau editor) sebelum bisa diterima khalayak.

Dalam komunitas HSC para pelajar tidak memiliki sistem kerja yang jelas. Sistem kerja HSC sangat cair dan tidak memiliki tuntutan tertentu. Berita-berita yang dihasilkan oleh para pelajar juga tidak melewati filter yang ketat sebelum bisa diunggah ke situs Hai Online. Selain itu, posisi para pelajar juga dapat dianggap setara dengan para wartawan Hai Online. Mereka tidak mengalami pembimbingan secara resmi lewat pelatihan jurnalistik secara rutin. Para pelajar mempelajari berbagai proses jurnalistik secara otodidak melalui pengalaman yang mereka alami. Menurut keterangan mantan pembina HSC, hal ini dilakukan agar para pelajar merasa nyaman beraktivitas di HSC, tidak merasa digurui. Untuk itu para pelajar diberikan fasilitas untuk mengembangkan diri. Redaksi Hai Online menempatkan diri mereka sebagai teman para pelajar, mereka belajar bersama-sama.

Proses objektivasi mulai terjadi ketika para informan mulai menjalankan aktivitas jurnalistik dengan menggunakan pola kegiatan yang mereka ciptakan berdasarkan rutinitas menjalani aktivitas jurnalistik. Proses jurnalistik meliputi pencarian bahan berita, peliputan berita, penulisan berita, publikasi berita, hingga evaluasi berita (Yunus, 2010). Para informan hanya melalui tiga tahap awal dari proses jurnalistik ini, yaitu tahap pencarian bahan berita, peliputan berita, dan penulisan berita.

Dalam tahap pencarian isu, para informan biasanya mencari isu dengan berbagai cara dan sumber. Di antaranya lewat redaksi Hai, riset internet, dan diskusi dengan teman sebaya. Kemudian dalam tahap pengumpulan fakta, para informan melakukannya dengan dua cara, yaitu observasi dan wawancara. Hanya satu informan, yang tidak menggunakan cara wawancara untuk mencari fakta karena mengalami kesulitan saat menjalankan praktik wawancara. Terakhir adalah tahap penulisan berita. Tahap ini menjadi tahap paling personal bagi para informan karena cara mereka untuk menulis berita berbeda satu sama lain. Ada informan yang tidak 
merasa kesulitan dan bisa langsung menulis saja. Ada juga yang harus mengumpulkan niat, mencari referensi tulisan, dan berdiskusi dengan banyak orang untuk bisa membangun konsep tulisan. Namun rata-rata, para informan menulis berita mereka dengan cara melakukan tinjauan ulang terhadap berbagai data yang mereka peroleh dari lapangan untuk kemudian menyeleksi bagian penting dari data yang diperoleh. Proses ini merupakan proses pelembagaan yang terjadi pada tahap objektivasi.

Selain pelembagaan, hal penting lainnya dalam tahap ini adalah pembuatan signifikansi atau tanda-tanda oleh manusia. Menurut Berger dan Luckmann sebuah tanda dapat dibedakan dari objektivasi-objektivasi lainnya, karena tujuan yang eksplisit untuk digunakan sebagai isyarat atau indeks bagi makna-makna subjektif. Proses signifikansi terjadi ketika informan berupaya membuat masyarakat di sekitar mereka mengetahui dan mengerti bahwa mereka adalah "wartawan" Hai Online yang sedang melaksanakan aktivitas jurnalistik. Proses signifikansi terjadi ketika para informan menggunakan kartu pers HSC untuk proses peliputan maupun pemuatan tulisan di situs Hai Online.

Salah seorang informan menyebutkan bahwa ketika dirinya meliput sebuah konser musik, ia tidak perlu lagi mengantri di jalur penonton biasa yang penuh sesak. Dengan menunjukan kartu pers, sang informan dapat masuk ke arena konser lewat jalur media. Aksinya saat itu sempat dipertanyakan oleh teman-temannya yang harus mengantri lewat jalur penonton biasa. Aksi Maria ini menunjukan bahwa ia telah menciptakan tanda yang bisa membuat orang lain mengerti bahwa dirinya sedang melakukan aktivitas jurnalistik sebagai seorang "wartawan". Kartu pers Maria jadi tanda bahwa ia adalah "wartawan” yang sedang bertugas.

Selain kartu pers, nama yang tertera di setiap tulisan pada informan yang dimuat di situs Hai Online juga menjadi bagian dari proses signifikasi. Hai Online menggunakan ketentuan bagi para anggota HSC untuk menyertakan identitas lengkap penulis berupa nama dan asal sekolah di ujung atau awal berita. Bukti identitas ini dapat digunakan informan untuk membuat masyarakat mengerti bahwa informan adalah anggota HSC yang aktif berpartisipasi di redaksi Hai Online sebagai penulis.

Penelitian ini juga menemukan bahwa bahasa memegang peranan penting dalam proses interaksi antara informan dengan orang-orang yang mereka temui saat liputan. Orang-orang yang seringkali ditemui informan tentu saja adalah narasumber dan sumber berita, sesama anggota HSC, redaksi Hai, jurnalis profesional, dan lain-lain. Para informan menggunakan bahasa melalui pilihan kata tertentu untuk menjelaskan aktivitas jurnalistik yang mereka lakukan. Peran bahasa ini sangat penting dalam tahap objektivasi sebagai alat simbolis untuk melakukan signifikansi. Pada tahap ini logika ditambahkan secara mendasar kepada dunia sosial yang diobjektivasi. Bangunan legitimasi disusun di atas bahasa dan menggunakan bahasa sebagai instrumen utama, sehingga pengetahuan tersebut bisa diterima sebagai sewajarnya oleh masyarakat (Bungin, H.M, 2009).

Selama menjalani pekerjaan mereka di komunitas HSC, para informan juga mengalami berbagai tantangan di dalam proses kerja jurnalistik yang mereka lakukan. Kemudian, para informan beradaptasi dengan menciptakan berbagai solusi untuk menghadapi tantangan yang ada sehingga mereka bisa tetap bekerja dengan baik. Biasanya tantangan terjadi dalam tahaptahap proses jurnalistik. Para informan masing-masing memiliki solusi yang berbeda untuk menghadapi masalah mereka masing-masing. Para informan biasanya selalu mempersiapkan diri dengan melakukan riset dan diskusi dengan pihak-pihak yang dirasa paham untuk bisa mengatasi masalah saat tahap wawancara dan observasi. Ada juga informan yang melakukan bujukan untuk bisa mewawancarai sumber berita yang agak ragu.

Selain tahap objektivasi, para informan juga mengalami tahap internalisasi lewat 
pengalaman yang mereka alami. Dalam tahap ini, para informan yang sudah mulai menemukan berbagai solusi tersebut nantinya akan dijadikan padanan dalam melakukan aktivitas jurnalistik seterusnya. Tahap ini akan terjadi terus menerus, karena tidak menutup kemungkinan para informan akan menghadapi banyak kendala lainnya yang kemudian akan mereka atasi dan jadikan pelajaran di masa depan. Setelah itu, para informan pasti akan menciptakan pola kerja mereka masing-masing sesuai pengalaman yang sudah mereka lewati, itulah yang membuat tahap yang mereka alami ini sebagai tahap internalisasi.

Selain itu, berbagai pengalaman yang dialami oleh para pelajar ini juga termasuk ke dalam penerapan salah satu elemen dalam sepuluh elemen jurnalisme menurut Kovach dan Rosenthiel, yaitu elemen kesepuluh, hak dan tanggung jawab warga. Maksud Kovach dan Rosenthiel dalam elemen kesepuluh tersebut adalah warga yang biasanya menjadi konsumen pasif kini tak lagi hanya bisa menunggu untuk membaca berita yang diberikan oleh redaksi media massa. Kini warga bisa juga secara aktif menggunakan hak mereka untuk mendapatkan informasi lewat tanggung jawab memberikan informasi lewat media massa. Dalam hal ini, para pelajar yang beraktivitas di dalam komunitas HSC menjadi salah satu penerapan elemen hak dan tanggung jawab warga menurut Kovach dan Rosenthiel.

Diagram 2. Motif Para Pelajar bergabung dengan Komunitas Hai School Crew

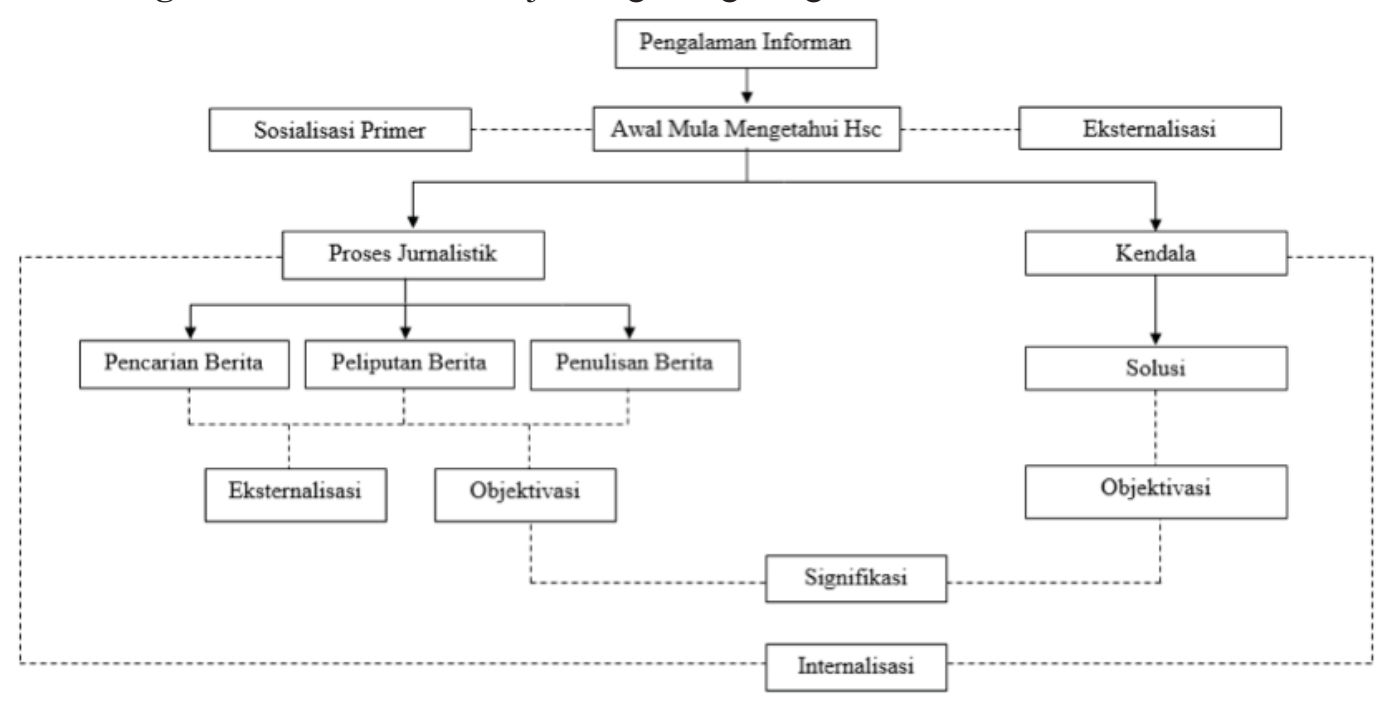

Sumber: Analisis Peneliti

\section{Pemaknaan terhadap Aktivitas Jurnalistik}

Selama menjadi anggota komunitas HSC, para informan dalam penelitian ini sudah menjalani berbagai pengalaman terkait aktivitas jurnalistik. Para informan sudah memperoleh pengalaman dalam melakukan proses jurnalistik yang meliputi pencarian bahan berita, peliputan berita, penulisan berita, publikasi berita, hingga evaluasi berita. Selama menjadi anggota komunitas HSC dan menjalankan berbagai aktivitas jurnalistik, para informan juga telah mempelajari banyak hal. Mereka mengetahui esensi dari aktivitas yang mereka lakukan tersebut. Oleh karenanya, para informan juga mengetahui apa makna aktivitas yang selama ini mereka lakukan dan apa makna komunitas HSC bagi mereka.

Merujuk pada proses inter-subjektif menurut Peter L. Berger dan Thomas Luckmann, para informan mengalami sebuah proses di mana anggota masyarakat berbagi persepsi dasar mengenai dunia yang mereka internalisasikan melalui sosialisasi dan memungkinkan mereka melakukan interaksi atau komunikasi. Proses inter-subjektif ini terdiri dari eksternalisasi, objektivasi, dan internalisasi.

Proses inter-subjektif pada tahap eksternalisasi terjadi sejak tahap pengembangan motif, 
pengenalan, dan penyesuaian dengan dunia jurnalistik. Tahap objektivasi terjadi ketika kemudian para informan melakukan aktivitas jurnalistik sebagai bagian dari rutinitas aktivitas. Setelah itu, para informan akan menyerap semua proses tersebut dan memaknai aktivitas jurnalistik yang mereka lakukan pada komunitas HSC. Tahap ini menjadi tahap internalisasi, yaitu tahap di mana para informan memasukkan kembali dunia sosio-kultural yang sudah diobjektivasi ke dalam kesadaran mereka (Berger, P. L., \& Luckmann, 2013:82).

Internalisasi yang dialami oleh para informan ini terjadi pada proses sosialisasi sekunder, yaitu internalisasi dari sejumlah "sub-dunia" yang berlandaskan lembaga. Sosialisasi sekunder merupakan proses memperoleh pengetahuan khusus sesuai dengan peranannya (role-specific knowledge). "Sub-dunia" yang diinternalisasi oleh individu dalam sosialisasi sekunder biasanya adalah kenyataan-kenyataan parsial, sesuatu yang berbeda dari "dunia dasar" yang sudah diperoleh sebelumnya dari tahap sosialisasi primer (Berger, P. L., \& Luckmann, 2013:189). Proses ketika para informan memperoleh pengetahuan khusus mengenai kejurnalistikan merupakan tahap sosialisasi sekunder. Dalam menjalankan aktivitas kejurnalistikan, para informan mengalami berbagai pengalaman yang akan membentuk pengetahuan khusus mereka. Pengetahuan khusus tersebut mendorong proses pemaknaan terhadap aktivitas jurnalistik. Pemaknaan ini mereka peroleh ketika mereka memiliki pengalaman dalam menjalankan aktivitas jurnalistik. Selain akan mampu memaknai aktivitas jurnalistik, para informan juga akan memiliki pengetahuan khusus lainnya dalam bidang jurnalistik berkenaan dengan etika jurnalistik, nilai berita, dan teknik penulisan berita.

Pengetahuan khusus yang didapatkan oleh para informan dalam bidang jurnalistik biasanya diperoleh secara otodidak. Komunitas HSC memang tidak memiliki sistem kerja yang ketat dan pembimbingan teoritis dari redaksi Hai Online. Para informan biasanya mempelajari berbagai hal mengenai jurnalistik melalui pengalaman yang diperoleh saat meliput dan membuat berita. Saat membuat berita, informan memerhatikan revisi apa saja yang dilakukan terhadap tulisan-tulisan mereka. Sedangkan saat meliput, informan belajar dari solusi yang mereka ciptakan terhadap kendala yang mereka alami di lapangan. Selain itu, para informan juga belajar melalui diskusi yang mereka lakukan dengan sesama teman anggota HSC dan para wartawan Hai Online. Mereka juga sesekali dibimbing langsung oleh para wartawan Hai Online yang menemani mereka melakukan liputan.

Dari hasil wawancara dan observasi peneliti, pembelajaran secara praktis seperti yang para informan alami ini berimbas pada cara para informan menyampaikan pengetahuan mereka. Hampir semua informan tidak bisa mendeskripsikan hal-hal yang mereka pelajari sesuai dengan definisi yang ada di buku panduan. Sebagian besar informan pun hanya berpegang pada standar moral yang mereka miliki.

Dalam hal etika jurnalistik, terdapat enam informan yang dapat mendeskripsikan pengetahuan mereka mengenai jurnalistik. Mereka menyebut tanggung jawab, pertimbangan moralitas, melindungi sumber berita, bersikap sopan dan professional, serta tidak menyebar hoaks sebagai etika jurnalistik. Hal-hal yang disampaikan oleh para informan ini sebagian besar sudah sejalan kode etik jurnalistik dan konsep mengenai tugas utama jurnalis menurut Kovach dan Rosenstiel (2001). Dalam hal menjalankan etika, para informan mengetahui apa yang dinamakan etika jurnalistik seperti harus menjalankan kejujuran, tidak melakukan plagiarisme, tidak menerima sogokan atau suap saat menjalankan peliputan, dan hal-hal lain yang sejalan dengan apa yang disebutkan dalam kode etik jurnalistik online versi Online Journalism Review (OJR) (Romli, 2012:47-48).

Para informan juga dapat menjelaskan konsep nilai berita serta konsep dan teknik penulisan berita. Menurut dua orang informan, sebuah informasi memiliki nilai berita jika 
terdapat subjek dan objek, menarik dan mudah dipahami, aktual dan jelas sumbernya. Sementara beberapa informan lainnya dapat mendeskripsikan konsep dan teknik penulisan berita, seperti menggunakan kaidah bahasa jurnalistik yang berkualitas, menarik, dan efektif.

Selanjutnya adalah proses pemaknaan yang dilakukan oleh para informan. Pemaknaan terhadap aktivitas jurnalistik yang dilakukan oleh para informan tidak jauh berbeda antara satu informan dengan informan lainnya. Bagi para informan, aktivitas jurnalistik adalah sebuah kegiatan mencari berita untuk kemudian dituangkan ke dalam bentuk tulisan sesuai fakta yang ada.

Selain pemaknaan terhadap aktivitas jurnalistik itu sendiri, para informan memperoleh makna kegiatan yang mereka lakukan di komunitas HSC secara lebih luas. Bagi para informan ini, aktivitas jurnalistik yang mereka lakukan lewat komunitas HSC adalah sarana penting pembelajaran mengenai dunia kerja, proses kerja, sistem kerja seorang jurnalis. Aktivitas jurnalistik yang mereka lakukan memungkinkan para pelajar ini lebih dulu mengenal dunia kerja dibandingkan dengan teman-teman sebaya mereka yang lain, sehingga mereka memiliki pengalaman yang lebih mendalam untuk persiapan masa depan.

Pemaknaan yang dimiliki oleh para informan ini berasal dari realitas yang mereka alami. Pemaknaan ini juga muncul akibat rutinitas yang para informan lakukan selama menjadi anggota komunitas HSC. Tahap ini merupakan bagian dari proses sosialisasi sekunder yang terjadi pada tahap internalisasi. Para informan mengalami sosialisasi sekunder saat mereka sudah menjalankan peran mereka berpartisipasi di redaksi Hai Online lewat komunitas HSC.

Dengan demikian, secara keseluruhan, makna yang dibangun oleh para informan diperoleh dari proses jurnalistik yang mereka jalani dan pengalaman yang mereka alami. Para informan mengalami tahap eksternalisasi dan objektivasi dalam pengalaman yang mereka alami. Setelahnya, mereka kemudian bisa menginternalisasi aktivitas jurnalistik yang mereka lakukan, sehingga mereka bisa memperoleh pengetahuan khusus di bidang jurnalistik, memiliki in-order-to motive (motif masa depan) atau tujuan yang ingin mereka capai, dan memaknai aktivitas jurnalistik yang mereka lakukan lewat komunitas HSC.

Hal-hal tersebut akan berlangsung berulang-ulang. Sejalan dengan yang dikatakan Berger dan Luckmann (2013:176), tahap eksternalisasi, objektivasi, dan internalisasi yang dialami oleh para informan memang tidak berlangsung dalam satu urutan waktu, tapi tiap bagian darinya secara serentak (simultan) dikarakterisasi oleh ketiga momen itu. Seperti digambarkan dalam bagan berikut ini.

Diagram 3. Motif Para Pelajar bergabung dengan Komunitas Hai School Crew

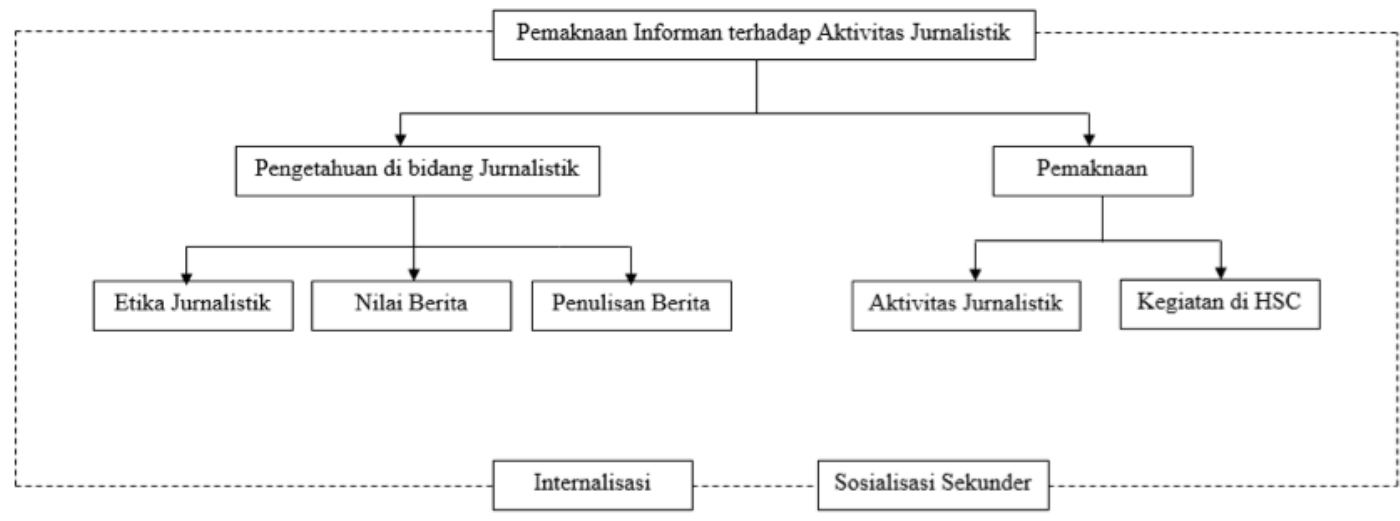

Sumber: Hasil Elaborasi Peneliti 
Volume 04 Nomor 01 Tahun 2020

DOI: $10.24198 / \mathrm{jkj} . \mathrm{v} 4 \mathrm{i} 1.26614$

\section{SIMPULAN}

Para pelajar anggota komunitas HSC memiliki motif-motif yang berbeda satu sama lain dalam mengikuti aktivitas jurnalistik di HSC. Motif terbanyak yang dimiliki oleh para informan adalah in-order-to-motive yaitu untuk meraih cita-cita. Hal ini menunjukan bahwa pengalaman yang dialami oleh para informan berhasil membentuk motif para informan untuk bisa meraih cita-cita mereka yang terkait dengan dunia kejurnalistikan baik menjadi jurnalis atau melanjutkan kuliah dalam bidang jurnalistik.

Aktivitas jurnalistik yang dilakukan oleh para informan berlangsung secara otodidak. Kendati para informan tidak bisa menjabarkan secara konseptual pengalaman yang mereka alami, para informan tetap mengetahui dan memaknai hal-hal esensial dalam dunia jurnalistik seperti kode etik atau teknik peliputan dan penulisan berita sejalan dengan konsep dan etika jurnalistik baku, atau memenuhi aspek moralitas dan kualitas (Annur \& Yudhapramesti, 2020). Para informan juga mengalami berbagai kendala selama menjalani pekerjaan mereka dan mencari serta mencari solusi secara otodidak.

Saat menjalankan aktivitas jurnalistiknya dalam komunitas Hai Online, para jurnalis pelajar ini melewati tahap-tahap eksternalisasi, objektivasi, dan internalisasi. Pada ketiga tahap ini terjadi juga tahap signifikansi dan inter-subjektivitas. Semua pengelaman ini membentuk konstruksi makna mengenai aktivitas jurnalistik. Menurut para pelajar jurnalis, bergabung dengan komunitas HSC sangat berdampak besar terhadap cara mereka memaknai profesi jurnalis dan aktivitas jurnalistik. Bagi pelajar jurnalis, komunitas HSC merupakan sarana untuk mengenal dunia kerja. Proses ini membantu para pelajar anggota komunitas HSC untuk mengenal diri mereka sendiri dan menentukan cita-cita yang ingin mereka capai di masa depan.

\section{DAFTAR PUSTAKA}

Anderson, W. (2017). Student Journalists Are Our Future-We Should Start Treating Them Like It. Diakses dari the Nation website: https://www.thenation.com/article/archive/ student-journalists-are-our-future-we-should-start-treating-them-like-it/

Annur, C. M., \& Yudhapramesti, P. (2020). Pemaknaan Etika Jurnalisme Warga oleh Jurnalis Warga NETCJ di Wilayah Solo. Jurnal Kajian Jurnalisme, 3(2), 122. https://doi. org/10.24198/jkj.v3i2.22167

Berger, P. L., \& Luckmann, T. (2013). Tafsir Sosial Atas Kenyataan. Jakarta: LP3ES.

Bowman, S., \& Willis, C. (2003). We Media: How audience are shaping the future of news and information. Diakses dari The Media Center at The American Press Institute website: http://sodacity.net/system/files/Willis-and-Bowman_We-Media-Ch1.pdf

Bradshaw, P. (2017). The Online Journalism Handbook: Skills to Survive and Thrive in the Digital Age (2th ed.). Routledge.

Bungin, H.M, B. (2009). Sosiologi Komunikasi. Kencana Prenada Media Group.

Bungin, B. (2008). Penelitian Kualitatif. Jakarta: Kencana Prenada Media Group.

Iqbal, M., \& Sjafirah, N. A. (2019). Makna Jurnalisme Warga Bagi Jurnalis Warga Netcj.Co.Id. Kajian Jurnalisme, 2(2). https://doi.org/10.24198/kj.v3i1.21364

Kovach, B., \& Rosenstiel, T. (2001). The Elements of Journalism. Jakarta: Pantau.

Kusumadiningrat, H. (2005). Jurnalistik: Teori dan Praktik. Bandung: Remaja Rosdakarya.

Kuswarno, E. (2007). Tradisi Fenomenologi Pada Penelitian Komunikasi Kualitatif Sebuah Pedoman Penelitian dari Pengalaman Penelitian. Sosiohumaniora, 9(2), 161-176.

Ritonga, R., \& Syahputra, I. (2019). Citizen journalism and public participation in the Era of New Media in Indonesia: From street to tweet. Media and Communication, 7(3 Civic Organizations in an Age of Distrust), 79-90. https://doi.org/10.17645/mac.v7i3.2094 
Volume 04 Nomor 01 Tahun 2020

DOI: $10.24198 / j k j . v 4 i 1.26614$

Romli, A. S. M. (2012). Jurnalistik Online: Panduan Mengelola Media Online. Bandung: Nuansa Cendekia.

Santoso, E. (2019). Peran jurnalisme warga dalam pemberdayaan masyarakat desa. Jurnal Kajian Komunikasi, 7(2), 224. https://doi.org/10.24198/jkk.v7i2.19601

Singer, J. ., Domingo, D., Heinonen, A., Hermida, A., Paulussen, S., Quand, T., ... Vujnovic, M. (2011). Participatory Journalism: Guarding Open Gates at Online Newspapers. Wiley-Blackwell.

Sulaeman, D., \& Hamalik, O. (1995). Psikologi Remaja: Dimensi-Dimensi Perkembangan. Bandung: Mandar Maju.

Yudhapramesti, P. (2007). Citizen Journalism (CJ) Sebagai Media Pemberdayaan Warga. Observasi, 5(1), 33-46.

Yunus, S. (2010). Jurnalistik Terapan. Bogor: Ghalia, Indonesia. 